\title{
乾燥中のシイタケ子実体の電気インピーダンス特性
}

\author{
河野俊夫 ${ }^{1} \cdot$ 北野雅治 $^{1} \cdot$ 松岡孝尚 $^{1} \cdot$ 石川勝美 $^{1} \cdot$ 正田慶夫 ${ }^{2}$ \\ ${ }^{1}$ 高知大学農学部 783-8502 南国市物部乙 200 \\ 2 愛媛大学農学部 790-8566 松山市樽味 3-5-7
}

\section{Electric Impedance Characteristics of 'Shiitake' Mushrooms during Drying}

\author{
Toshio KAWANO ${ }^{1}$, Masaharu KITANO ${ }^{1}$, Takahisa MATSUOKA ${ }^{1}$, \\ Katsumi ISHIKAWA ${ }^{1}$ and Yoshio HIKIDA ${ }^{2}$ \\ ${ }^{1}$ Faculty of Agriculture, Kochi University, Monobe 200, Nankoku, 783-8502 Japan \\ ${ }^{2}$ Faculty of Agriculture, Ehime University, Tarumi 3-5-7, Matsuyama, 790-8566 Japan
}

\begin{abstract}
For the purpose of monitoring the interior state of 'Shiitake' mushrooms during drying, especially for estimating the moisture conditions, electric impedance of the cap was measured in a frequency range of $42 \mathrm{~Hz}$ to $5 \mathrm{MHz}$ and in a moisture range of $133.1 \%$ d.b. to $1671 \%$ d.b.

Cole-Cole plots showed that the circular-arc shape in the plot-curve characteristic of agricultural products disappeared as drying progressed.

The dependency relationship plots of logarithmic resistance to moisture content were divided into two parts at the turning point; one showed linear relationships and the other exponential. A moisture estimating formula at $42 \mathrm{~Hz}$ of measuring frequency was proposed and its parameters were calculated by the non-linear curve fitting method. The formula had an estimation error of $10.0 \%$ in the higher moisture region of more than $590.2 \%$, d.b. and $17.4 \%$ in the areas with a moisture content below that threshold on an average relative error basis.
\end{abstract}

Keywords : drying, electric impedance, monitoring, 'Shiitake’ mushrooms

\begin{abstract}
緒言
乾燥中のシイタケ子実体 ( 以下, シイタケとする) の状態を

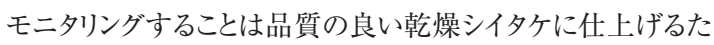
めに欠かせない. シイ夕ケはほだ木の置かれた環境や収穫時 期によって, 雨子や日和子と呼ばれるように, 初期含水率にば らつきを生じやすいため, 標準的な乾燥温度プログラムはあっ ても万能ではなく, 乾燥するシイタケの状態をモニタリングしな
\end{abstract}

2005 年 6 月 30 日受付

2006 年 5 月 11 日受理

Coressponding author: Toshio Kawano (tkawano@kochi-u.ac.jp)
がら適切な乾燥処理を行わなければ良質の乾燥シイタケの歩 留まりを高めることは難しい. 乾燥過程での色や形のモニ多 ングは画像処理に行うことができる. しかし, 乾燥中のシイタケ の内部状態は NMR やその他の大型機器によらねば知ること はできず, 乾燥器のように小型で安価な機器にはそぐわない. 物体の内部状態を簡便にモニ㚈ングする方法としてイン ピーダンス特性を利用する方法が多方面で活用されている. インピーダンスの等価回路モデルとして現在でもよく用いられ る Hayden モデルを提案した, Hayden らによるジャガイモとア ルファルファのインピーダンス特性に関する研究報告 (Hayden et al., 1969) を始めとして, 梨 (Kato, 1988), リンゴ (Kato, 1989), 大根・かぼちゃ (Nakamura et al., 1992), 炊飯米 (Takeuchi and Toyoda, 2000), カキ・桃 (Kato, 1993), 人 
体 (たとえば Jakko and Robert, 1995), 魚肉 (Kato et al., 2000a; 2000b), 樹木 (Yamaura, 2000; 2001a; 2001b) などで ある. これらのほとんどは高水分であり, Haydenの等価回路 モデルによく適合するため, 得られた Hayden モデルのパラ メーターを利用して鮮度や内部状態の推定が行われている. しかし, 乾燥の進行に伴い含水率が減少する乾燥シイ夕ケ の場合は, 乾燥の初期では Cole-Cole プロット上で Hayden モデルに特徵的な円弧状のインピーダンス特性を示すが, 含 水率の低下に伴い Hayden モデルの適合性が低くなる.この

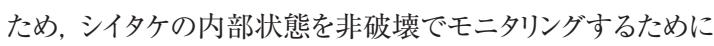
は, 乾燥の進行に伴うインピーダンス特性の変化をもとに別の 方法によって行う必要がある.

そこで本研究では, シイタケの内部状態のうち, 乾燥プロセ スを制御する上で重要となる含水率をインピーダンス特性によ って推定する方法について検討した.

\section{材料および方法}

実験材料のシイタケは平成 17 年 5 月高知県南国市で収 穫したもの (初期平均含水率 1399\% d.b., 標準偏差 116.5\% d.b.) で, 1 回の乾燥実験で 25 枚使用し, 2 回反復して実験 を行った. 絶乾量の測定は, シイタケを 16 分割に裁断して $105^{\circ} \mathrm{C}-24 \mathrm{~h}-0.009 \mathrm{~kg} / \mathrm{kg}$ 常圧定温乾燥する方法によりすべ

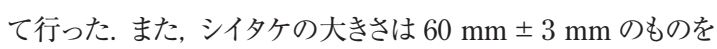
選別し, 計測径の位置に印をつけ, インピーダンス計測時の 電極接触位置とした. 未乾燥試料用の生シイタケ 5 枚を除く 20 枚の乾燥用シイタケは, プログラム制御乾燥器 (ASONE DO-450) 内で, 初期 $40^{\circ} \mathrm{C}$ から乾燥を始め, 2, 4 時間経過ご とにそれぞれ $10^{\circ} \mathrm{C}$ 昇温させ, 7 時間乾燥を行った. この階段 乾燥方式は, 生産現場での慣行乾燥方式に準じたものであ る. この乾燥の間, 温度のステップ上昇直前にシイタケを 5 枚 ずつ, 室温 $25^{\circ} \mathrm{C}$ に設置した乾燥機内に図 1 に示す測定装 置で 1 枚ごとのインピーダンスを測定し, その後質量計測を経 て絶乾した. インピーダンス測定装置には非破壊接触式でイ ンピーダンスを測定する方法を採用した，接触式のインピーダ ンスは, 接触圧力により変化するため, シイタケのかさ部直径 方向を二枚の接触ステンレスシート (一辺 $20 \mathrm{~mm}$, 厚さ 0.5 $\mathrm{mm}$ ) で挟み, 可動部横に取り付けたスケール (デジタルノギ 久, 日本測定具 PRO-MAX200R, 最小直読值 $0.01 \mathrm{~mm}$, 繰 り返し精度 $0.01 \mathrm{~mm}$ ) によりバネの縮みが一定となるよう, ボル トの締め付けによってかさ部に荷重 $(3.0 \mathrm{~N})$ を加える方式とし た. なお, バネの縮みはあらかじめ荷重装置により測定したバ ネ定数をもとに $3.0 \mathrm{~N}$ となる長さを計算により求めた. シイタケ のインピーダンスは, 負荷電圧線と負荷電流線とを分離する 4 線方式のインピーダンス計 (HIOKI LCR HI-Tester Model

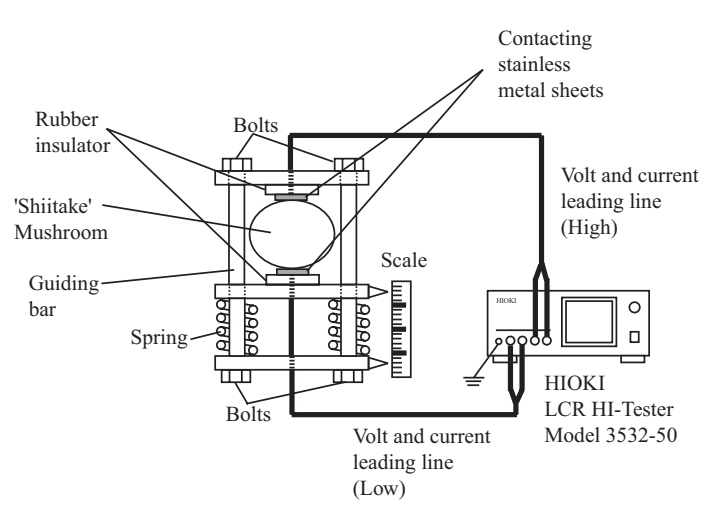

Fig. 1 Schematic diagram of the apparatus for measuring electric impedance of 'Shiitake' mushrooms

3532-50) により周波数 $42 \mathrm{~Hz}$ から $5 \mathrm{MHz}$ に亘る範囲で負 荷電圧 $0.5 \mathrm{~V}$ で測定した. インピーダンス計測時には毎回, OPEN/SHORT 操作による計測系の寄生インピーダンス補正 を行った，測定周波数は, 等間隔ではインピーダンス特性の 一部に偏って計測をすることになるため, $42 \mathrm{~Hz}$ から $5 \mathrm{MHz}$ の 範囲を対数上で 100 等分した.

\section{結果および考察}

\section{1. 慣行乾燥方式によるシイタケの乾燥特性}

図 2 は, 慣行乾燥方式による階段昇温乾燥を行った場合 の乾燥空気温度, 試料温度の変化及び初期含水率 $1480 \%$ d.b.のシイ夕ケの含水率変化である. また, 図 3 は含水率の 経時変化から, 数值微分により求めたシイタケの乾燥速度特 性である. $40^{\circ} \mathrm{C}$ から $60^{\circ} \mathrm{C}$ まで温度をステップ上昇させる乾燥 方法により乾燥速度が大きく変動することなく一定割合で乾燥 速度が低下する傾向を示している. 乾燥理論の点では, この ような階段昇温方式による乾燥特性は, 各階段温度に対応 した乾燥速度直線の折れ線をつづり合わせた形になるものと 考えられる. しかし, 含水率の低下に伴い, 各階段温度での 乾燥速度も順次低下し, また図 2 に見られるように, 乾燥空 気温度の階段状の変化に対して試料温度の変化は緩やかな ために, 理論から推察される折れ線の傾向が緩和され, 直線 変化のように見えるものと考えられる. 生産現場で行われる慣 行の乾燥方式は経験的に乾燥速度が一定となることが知ら れている (e.g. Hirao, 1986) が, 乾燥速度曲線上からもその 傾向が確認できる. 図 3 によれば乾燥速度は $600 \%$ d.b. 前後 を境として乾燥速度直線の傾きが変わっている. この傾向は シイタケの乾燥特性のモデル解析 (Kawano et al., 2005)に おいても観測された結果である. 乾燥速度の特性が変化す 


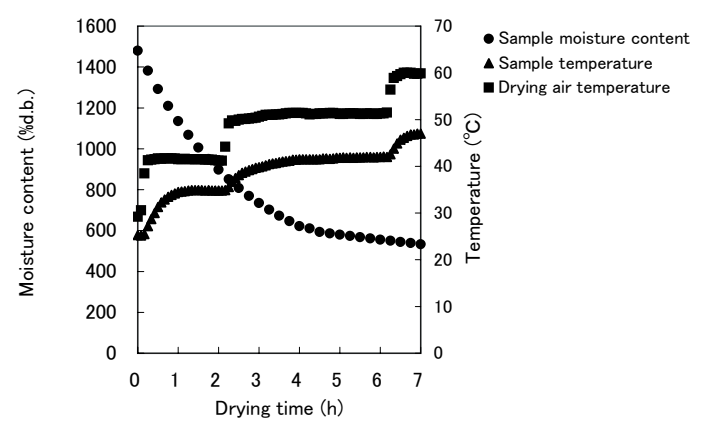

Fig. 2 Changes of the sample temperature, moisture content and air termperature during drying (Sample initial moisture content: $1480 \%$ d.b.)

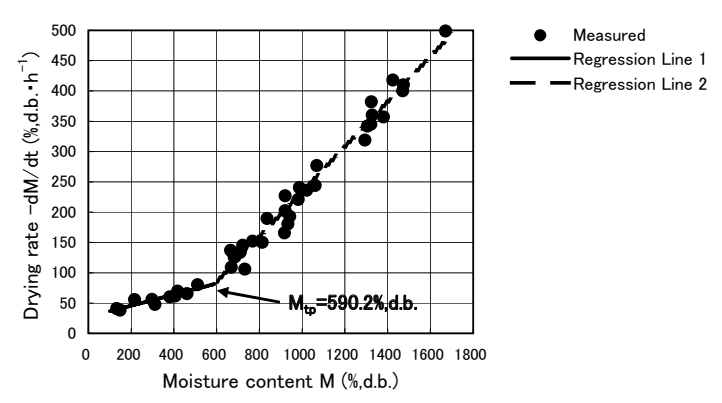

Fig. 3 Drying rate characteristics of Shiitake mushrooms

る境界含水率を求めるため, $600 \%$ d.b. 以上のデー夕および $600 \%$ d.b. 以下のデー夕について次の直線回帰式へ最小自 乗法により当てはめ係数を求めた.

$$
-\frac{d M}{d t}=k M+b
$$

その結果, $600 \%$ d.b. 以上の含水率領域では $\mathrm{k}=0.372$ $\mathrm{h}^{-1}, \mathrm{~b}=-138.0 \% \mathrm{~h}^{-1}, 600 \% \mathrm{~d} . \mathrm{b}$. 以下の含水率領域では $\mathrm{k}=$ $9.128 \times 10^{-2} \mathrm{~h}^{-1}, \mathrm{~b}=27.44 \% \mathrm{~h}^{-1}$ が得られた.これらの回帰直 線の交点により乾燥速度特性の変化する含水率を求めると $590.2 \%$ d.b. となった.

\section{2. 乾燥に伴うインピーダンス特性の変化}

図 4 は, 測定周波数を $42 \mathrm{~Hz}$ から $5 \mathrm{MHz}$ の範囲で測定 した含水率 1671\%, d.b. (無乾燥試料 ), 1061\% d.b., 836\% d.b., $512 \%$ d.b., $407 \%$ d.b. のシイタケのインピーダンス Z のレ ジスタンス $\mathrm{R}$ と容量リアクタンス X との関係を示した, ColeCole プロットである. 農産物に限らず含水率の高い物質のイ ンピーダンス特性は，一般に円弧状の特性曲線を示すことが 報告されている (Fujii et al., 1984; Kato, 1988; Kato, 1989; Nakamura et al., 1992; Kato, 1993; Jakko and Robert,

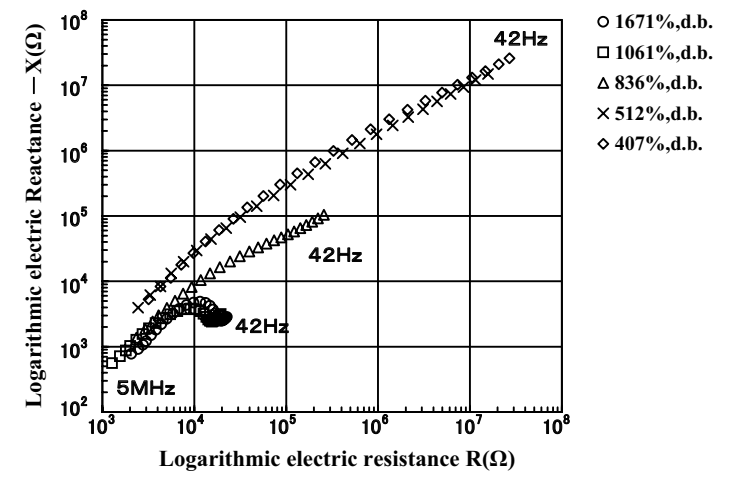

Fig. 4 Electric resistance and reactance changes of Shiitake mushrooms with frequency at five different moisture contents (Cole-Cole plot)

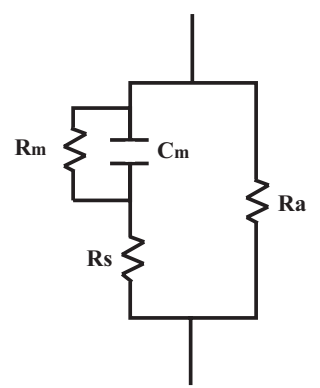

(A) Hayden model

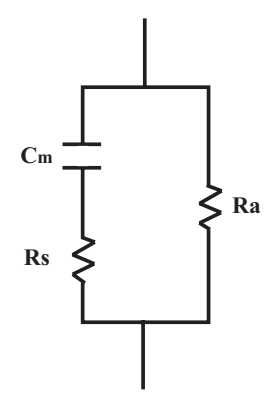

(B) Simplified Hayden model

\begin{abstract}
$\mathrm{Cm}$ : Cell membrane capacitance
$\mathrm{Ra}$ : Extracellular fluid resistance

Rm: Cell membrane resistance
\end{abstract}

Rs : Intracellular fluid resistance

Fig. 5 Equivalent circuits suitable for biomaterials

1995; Kato et al., 2000a, 2000b) が, シイタケの場合も収穫 直後の無乾燥試料では図中に示すように円弧状の特性を示 した. 乾燥によって含水率が低下するに従い, インピーダンス 特性曲線の円弧部分は次第に消失し, インピーダンスは大きく なる. 乾燥速度特性からは $590.2 \%$ d.b. を境に乾燥速度に違 いが見られた。一方，インピーダンスの特性では $512 \%$ d.b. 以 下の領域では曲線に $\mathrm{S}$ 字状の曲線は見られないのに比べ, 836\% d.b. 以上の領域では低周波において S 字状の曲線傾 向が強くなり, $512 〜 836 \%$ d.b. の間にインピーダンス特性が 変化する境界含水率が存在することを示唆している. すなわ ち, 含水率の変化とインピーダンスの特性変化との間に相互 に関連性のあることがわかる.

ところで, インピーダンスの特性を分析する上では, シイタケ 
の細胞組織構造を考慮した等価回路を考える必要がある. 図 5(A) は, 生物材料の等価回路として基本モデルとなった Hayden の等価回路モデル (Hayden et al., 1969) である. 細 胞組織は一般に Rm> Ra, Rs であるので (e.g. Zhang et al., 1993; Repo and Zhang, 1993), シイタケの場合も同様に図 5(B) の簡略型の Hayden モデルを等価モデルとするのが適 当と思われる. この簡略型 Hayden モデルのインピーダンス Z は, 周波数依存部分である $\mathrm{Cm}$ を $\mathrm{Zm}$ とインピーダンス表記 すると, 次のように表される.

$$
Z=R-j X=\frac{R_{a} R_{s}+R_{a} Z_{m}}{\left(R_{a}+R_{s}\right)+Z_{m}}
$$

周波数 $\mathrm{f}$ がゼロ (直流) の場合, $Z_{\mathrm{m}}$ は無限大となり, 全体 インピーダンス $\mathrm{Z}$ の值は $\mathrm{R}$ 単体に等しく, 周波数 $\mathrm{f}$ が無限大 になるにしたがって Z は $\mathrm{C}_{\mathrm{m}}$ を除いた $\mathrm{R}_{\mathrm{a}}$ と $\mathrm{R}_{\mathrm{s}}$ の並列回路とな る. (2) 式を解いて周波数 $\mathrm{f}$ を消去すると, 最終的にインピー ダンスのレジスタンス $\mathrm{R}$ と容量リアクタンス X との間の周波数 軌跡の方程式として次式が誘導できる.

$$
\left\{R-\frac{R_{a}\left(R_{a}+2 R\right)}{2\left(R_{a}+R_{s}\right)}\right\}^{2}+X^{2}=\left\{\frac{R_{a}^{2}}{2\left(R_{a}+R_{s}\right)}\right\}^{2}
$$

これは円の方程式でその中心は $\mathrm{R}$ 軸上に存在すること になる. しかし多くの測定例 (e.g. Sugiyama et al., 1987; Nakamura et al., 1992) が示すように, 一般には R と X の軌 跡である Cole-Cole 円の中心は $\mathrm{R}$ 軸上にはなく, $\mathrm{R}$ 軸よりも 下側となる. このような場合, 等価回路モデルのインピーダンス 式は次式で表現できる (Yamamoto et al., 1992).

$$
Z=R-j X=Z_{\infty}+\frac{Z_{0}-Z_{\infty}}{1+(j \omega \tau)^{\beta}}=Z_{\infty}+\frac{2 r}{1+(j \omega \tau)^{\beta}}
$$

ここに,

$\mathrm{Z}_{0}, \mathrm{Z}_{\infty}$ : 実測の $\mathrm{R}-\mathrm{X}$ プロットから得られる Cole-Cole の 円が $\mathrm{R}$ 軸上と交わる点 $\left(Z_{0}>Z_{\infty}\right)$

$\alpha$ : Cole-Cole 円弧の中心角 $(\Omega)$

$\beta$ : 中心角 $\alpha$ にって決まる係数 $(=\alpha / \pi, \Omega)$

$\omega$ : 角速度 $\left(=2 \pi \mathrm{f}, \operatorname{Rad} \cdot \mathrm{s}^{-1}\right) \quad \mathrm{f}$ : 測定周波数 $(\mathrm{Hz})$

$\tau$ : 時定数

r: Cole-Cole 円の半径 $(\Omega)$

(4) 式中, r とßは Cole-Cole プロットの円弧の広がりを表す 指標である. (3) 式と同様に (4) も同様に円の方程式である が, 中心は $\mathrm{R}$ 軸より下となる. 図 6 は試料のインピーダンス測 定值全体のデータを用いて最小自乗法により計算した ColeCole 円の半径 $\mathrm{r}$ および $\beta$ と含水率の関係を示したものである. 半径 $\mathrm{r}, \beta$ 共に含水率の低下と共に増加し, Cole-Cole プロッ

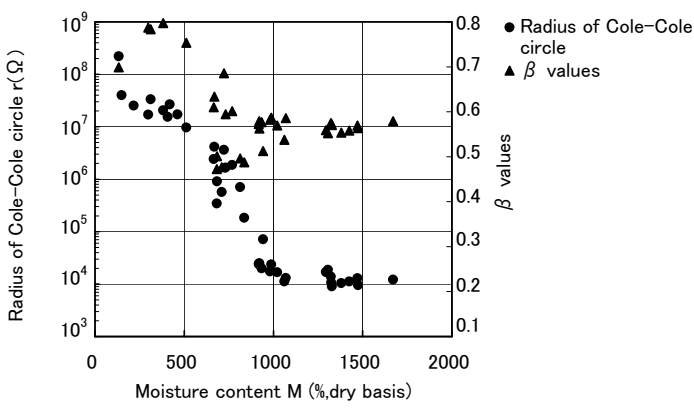

Fig. 6 Values of radius and $\beta$ of Cole-Cole circle

トの円弧が大きく広がると同時に中心点が $\mathrm{R}$ 軸上に近い位置 に接近する傾向がある.

3. 含水率とリアクタンスの関係

試料インピーダンスは一般に含水率と温度との関数である ので, 温度変化による影響が少なからずあるが, ここでは温 度履歴を生産現場での階段昇温方法を前提とすることで, 乾 燥中のシイタケのインピーダンスを含水率の関数として求めるこ とにする.

図 7, 図 8 に $42 \mathrm{~Hz}, 13.66 \mathrm{kHz}, 1.536 \mathrm{MHz}$ におけるシイ タケのリアクタンス $\mathrm{X}$ と含水率 $\mathrm{M}$ との関係, およびレジスタン ス R と含水率との関係を示す. どちらの関係もきわめて傾向 が似ており, 乾燥速度曲線で明らかになった, 乾燥特性の変 化が起こる境界含水率である $590.2 \%$ d.b. 前後を境に曲線の 傾向に変化が見られる. 含水率とリアクタンスもしくは含水率と レジスタンスとの間の関係を定式化できれば, 含水率の推定 に役立つと思われるが, 含水率変化に基づく等価回路素子 の特性変化を考慮した等価回路の設計はたいへん困難であ る. そこでこれらの関係に対する実験式を求めて代用するこ ととする. 乾燥状態の変化に最も敏感な周波数は, 今回の測 定範囲では $42 \mathrm{~Hz}$ の時である. リアクタンスに比ベ, レジスタン スは測定が容易であること, また $42 \mathrm{~Hz}$ については低含水率 でリアクタンスよりも, 電極分散による影響とも考えられるが, ば らつきが小さいことから, 含水率を推定する実験式の説明変 数としてレジスタンス Rを用いる.

図 8 のレジスタンス $\mathrm{R}$ の傾向は, 乾燥速度の低下傾向に 変化の見られる境界含水率 $\mathrm{M}_{\mathrm{tp}}$ を境として, 高含水率側で は含水率 $\mathrm{M}$ の増加に対して指数関数的に $\mathrm{R}$ が減少する傾 向を示し, 一方, $\mathrm{M}_{\mathrm{tp}}$ よりも低含水率側では含水率の増加に 伴い直線的に減少する傾向が見られる. そこでこれらの関係 は次の実験式で表現できる.

$\mathrm{M}>\mathrm{M}_{\mathrm{tp}}$ の時

$$
\frac{\ln R-\ln R_{\infty}}{\ln R_{t p}-\ln R_{\infty}}=\delta \exp (-\varepsilon M)
$$




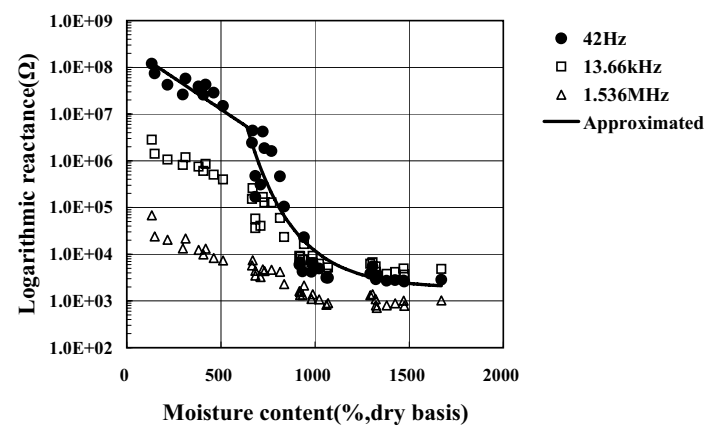

Fig. 7 Relationships between electric reactance and moisture content of Shiitake mushrooms at three different measuring frequencies

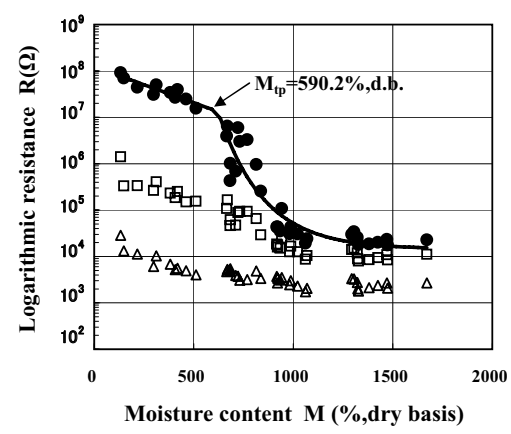

- $42 \mathrm{~Hz}$

ㅁ $13.66 \mathrm{kHz}$

$\Delta 1.536 \mathrm{MHz}$

- Approximated

Fig. 8 Relationships between electric resistance and moisture content of Shiitake mushrooms at three different measuring frequencies

$\mathrm{M} \leqq \mathrm{M}_{\mathrm{tp}}$ の時

$\ln R=\ln R_{0}-\gamma M$

ここに,

$\mathrm{R}_{\mathrm{tp}}$ : 境界含水率 $\mathrm{M}_{\mathrm{tp}}$ の時のレジスタンス $(\Omega)$

$\mathrm{R}_{\infty}$ : 保水可能な最高含水率時のレジスタンス $(\Omega)$

$\mathrm{R}_{0}:$ 乾物のレジスタンス $(\Omega)$

$\delta, \varepsilon, \gamma:$ 係数

これらより,レジスタンス $\mathrm{R}$ から含水率 $\mathrm{M}$ を求める式として, 次式を得る.

$\mathrm{R}<\mathrm{R}_{\mathrm{tp}}$ の時 $\left(\mathrm{R}_{\mathrm{tp}}\right.$ は $\mathrm{M}_{\mathrm{tp}}$ に対応するレジスタンス $)$

$$
M=\frac{1}{\gamma} \ln \left(\frac{R_{0}}{R}\right)
$$

$R \geqq R_{\mathrm{tp}}$ の時

$$
M=\frac{1}{\varepsilon} \ln \left\{\frac{\delta \ln \left(\frac{R_{t p}}{R_{\infty}}\right)}{\ln \left(\frac{R}{R_{\infty}}\right)}\right\}
$$

Marquartdt-Levenberg 法により $\mathrm{M}_{\mathrm{tp}}$ を境とする二つの含 水率領域の測定デー夕をそれぞれ (7) 式と (8) 式に当ては め, $\mathrm{R}_{\mathrm{tp}}, \mathrm{R}_{0}, \mathrm{R}_{\infty}, \gamma, \delta, \varepsilon$ の值を推定した結果, $\mathrm{R}_{\mathrm{tp}}=1.491 \times$ $10^{7}(\Omega), \mathrm{R}_{0}=1.236 \times 10^{8}(\Omega), \mathrm{R}_{\infty}=1.4426 \times 10^{4}(\Omega)$, $\gamma=3.583 \times 10^{-3}, \delta=15.57, \varepsilon=4.434 \times 10^{-3}$ を得た. 図 8 にこれらの值を用いて (7) 式および (8) 式で計算した近似結 果を実線で示す. 図中の $\mathrm{M}_{\mathrm{tp}}$ はシイタケの乾燥速度が変わ り乾燥状態の変化の起こる境界含水率の推定值で, $590.2 \%$ d.b. である. 求められた係数を利用して実験式 (7) と (8) を 使うことにより, シイタケのレジスタンスと含水率との間の傾向を 表すことができた. 実験式による含水率の予測值の, 実測值 に対する精度を評価するため, 次式で表される平均相対誤 差 $\mathrm{E}$ を求めることにする.

$$
E=\frac{\sum_{i=1}^{N}\left|\frac{M_{\text {est }}-M_{\text {mea }}}{M_{\text {mea }}}\right|}{N} \times 100(\%)
$$

\section{ここに}

Mest: 実験式による推定含水率 (\% d.b.)

$\mathrm{M}_{\text {mea: }}$ 実測含水率 (\% d.b.)

$\mathrm{N}$ : 直線部または曲線部のデー夕数

$\mathrm{E}$ によれば直線部が $\mathrm{E}=17.4 \%$ ，曲線部が $10.0 \%$ となり， 含水率の低い領域で含水率の推定精度が低下している. この方法を用いれば, たとえば乾燥機内にある複数枚のシ

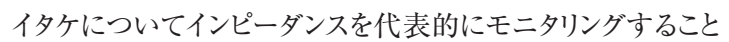
で, 慣行の生産現場での階段昇温乾燥による乾燥中のシイ夕 ケの仕上がり具合 (乾燥速度や含水率のばらつき情報 )を 把握することができ，良質の乾燥シイタケを得ることができるよ うになると思われる。

本研究ではかさ部直径間のみのインピーダンス特性からシ イ夕ケの含水率を推定する方法について検討した. 今後の課 題として, 測定点として複数点とることで含水率の推定精度を 向上させる方法, および乾燥中のインピーダンス測定における 温度の影響について検討することが必要である. この研究で は, 慣行の生産現場で行われている階段昇温乾燥法を前提 に, 含水率をインピーダンスのみの関数として検討し推定式を 導きだした.一般にはインピーダンス特性は温度と含水率の関 数と考えられるので, 任意の乾燥履歴による含水率推定に用 いるためには, 多段階の恒温乾燥による乾燥特性と, それに 伴うインピーダンス特性の変化に関する基礎デー夕を蓄積し解 析する必要がある。 


\begin{abstract}
また，低周波域での測定の場合，1）電極と試料間の接触 状態の影響を受けやすい, 2) 測定系の近傍の誘電体や電 磁誘導源の影響を受けやすい, 3) 42Hzでの測定の場合に は交流電源周波数に近く影響を受けやすいなどの, 装置の 構造や電磁的な環境に起因する外乱要素の影響が混入す る可能性があるので, 応用上はこれらの影響についても検討 が必要である。
\end{abstract}

\section{摘要}

乾燥中のシイタケの内部状態, 特に含水率状態をモニ夕リ ングする目的で, シイタケのかさ部の電気インピーダンスを, 周 波数 $42 \mathrm{~Hz} \sim 5 \mathrm{MHz}$, 含水率 $133.1 \%$ d.b. 〜 1671\% d.b.の 範囲について測定した.

Cole-Cole プロットの結果, 農産物に特徴的なプロット上の 円弧が乾燥の進行に伴い消失することがわかった.

電気インピーダンス対数值の含水率依存関係は, 境界点 で二つの部分, すなわち直線部分と指数関数の部分とに分 割することができることがわかった. 測定周波数 $42 \mathrm{~Hz}$ に対 する含水率推定式を提案し, パラメーターを非線形の当ては めにより求めた. その結果, 提案した式は $590.2 \%$ d.b. 以上 の含水率域で $10.0 \%$, それ以下の含水率で $17.4 \%$ の相対誤 差を持つことがわかった.

\section{引用文献}

Fujii, Y., Hayashi, T., Yasuda, T. 1984. Nutritional diagnosis of phosphorus by electric impedance measurement in plant. Japan. J. Soil Sci. and Plant Nutri. 55(4): 305-310.

Hayden, R. I., Moyse, C. A., Calder, F. W., Crawford, D. P., Fensom, D. S. 1969. Electric impedance studies on Potato and alfalfa tissue. J. Experimental Botany 20(63): 177-200.

Hirao, T. 1986. The drying method of 'Shiitake' mushrooms. Nobunnkyo, Tokyo, 1-172.

Jaakko, M., Robert, P. 1995. Bioelectromagnetism: Principles and Applications of Bioelectric and Biomagnetic Fields. Oxford University Press. 1-512.

Kato, K. 1988. Nondestructive measurement of fruits quality by electrical impedance (Part 1) -Relation between impedance parameters and freshness-. J. Japan. Soc. Agr. Mach. 50(6): 99-107.

Kato, K. 1989. Nondestructive measurement of fruits quality by electrical impedance (2) -Influence of peel on measurement and calculation of internal properties-. J. Japan. Soc. Agr. Mach. 51(5): 55-61.

Kato, K. 1993. Nondestructive measurement of fruits quality by electrical impedance (Part 3) -Internal quality evaluation by immersion comparison method-. J. Japan. Soc. Agr. Mach. 55(1): 75-83.

Kato, K., Sakaguchi, M., OoI, Y., Maruo, S., Toyoda, K. 2000a. Measurement of the freshness of fish by impedance spectroscopy (Part 1) -Electrical characteristics of fish and selection of high frequency freshness indices-. J. Japan. Soc. Agr. Mach. 62(3): 76-83.

Kato, K., Sakaguchi, M., OoI, Y., Maruo, S., Toyoda, K. $2000 \mathrm{~b}$. Measurement of the freshness of fish by impedance spectroscopy (Part 2) -Variation of high frequency freshness indices and estimation of ice storage time-. J. Japan. Soc. Agr. Mach. 62 (5): 59-69.

Kawano, T., Kitano, M., Matsuoka, T., Ishikawa, K. 2005. Analysis of the Drying Characteristics Model of 'Shiitake' mushrooms. J. SHITA. 17(3): 144-149.

Nakamura, T., Yamamoto, Y., Song, Z., Yamamoto, T. 1992. New equivalent circuit for electrical impedance of botanical tissues. The IEICE Trans. on Information and Systems, Part 2 (Japanese Ed.) Vol. J75 -D- II (No.11): 1975-1977.

Ousaka, T., Koyama, N., Osaka, T. 2003. Electrochemistry method -Basic measurement manual-. Kodansya Scientific, Tokyo, 1-199.

Repo, T. and Zhang, M. I. N. 1993. Modelling woody plant Tissues using a distributed electrical circuit. J. Exp. Bot. 44(262): 977-982.

Sugiyama, J., Hayashi, T., Hirouchi, H. 1987. Electrical impedance of Kiwi fruit (Studies on electrical quality evaluation of fruits and vegetables Part I ). J. Japan. Soc. Food Sci. 34(11): 725-730.

Takeuchi, R., Toyoda, K. 2000. Characterization of rice cooking process by electrical impedance measurements. Bulletin of Gifu Woman' s College. (29): 155-159.

Yamaura, I., 2000. New century for human and plants (First Part). In: SAWS 2000 (Vol.11), ed. by Kikusui electric industry, Yokohama, 2-5.

Yamaura, I., 2001a. New century for human and plants (Second Part). In: SAWS 2001 (Vol.12), ed. by Kikusui electric industry, Yokohama, 2-5.

Yamaura, I., 2001b. New century for human and plants (Last part). In: SAWS 2001 (Vol.13), ed. by Kikusui electric industry, Yokohama, 2-5.

Zhang, M. I. N., Willison, J. H. M., Cox, M. A., Hall, S. A. 1993. Measurement of heat injury in plant tissue by using electrical impedance analysis. Can. J. Bot. 71: 1605-1611. 